\title{
Worker separations in a nonstationary corporate environment
}

Citation for published version (APA):

Dohmen, T. J., \& Pfann, G. A. (2004). Worker separations in a nonstationary corporate environment. European Economic Review, 48(3), 645-663. https://doi.org/10.1016/S0014-2921(03)00067-9

Document status and date:

Published: 01/01/2004

DOI:

10.1016/S0014-2921(03)00067-9

Document Version:

Publisher's PDF, also known as Version of record

\section{Please check the document version of this publication:}

- A submitted manuscript is the version of the article upon submission and before peer-review. There can be important differences between the submitted version and the official published version of record.

People interested in the research are advised to contact the author for the final version of the publication, or visit the DOI to the publisher's website.

- The final author version and the galley proof are versions of the publication after peer review.

- The final published version features the final layout of the paper including the volume, issue and page numbers.

Link to publication

\footnotetext{
General rights rights.

- You may freely distribute the URL identifying the publication in the public portal. please follow below link for the End User Agreement:

www.umlib.nl/taverne-license

Take down policy

If you believe that this document breaches copyright please contact us at:

repository@maastrichtuniversity.nl

providing details and we will investigate your claim.
}

Copyright and moral rights for the publications made accessible in the public portal are retained by the authors and/or other copyright owners and it is a condition of accessing publications that users recognise and abide by the legal requirements associated with these

- Users may download and print one copy of any publication from the public portal for the purpose of private study or research.

- You may not further distribute the material or use it for any profit-making activity or commercial gain

If the publication is distributed under the terms of Article $25 \mathrm{fa}$ of the Dutch Copyright Act, indicated by the "Taverne" license above, 


\title{
Worker separations in a nonstationary corporate environment
}

\author{
Thomas J. Dohmen ${ }^{\mathrm{a}, *}$, Gerard A. Pfann ${ }^{\mathrm{a}, \mathrm{b}, \mathrm{c}}$ \\ anstitute for the Study of Labor (IZA), P.O. Box 7240, 53072 Bonn, Germany \\ ${ }^{\mathrm{b}}$ Maastricht University, $6200 \mathrm{MD}$, Maastricht, The Netherlands \\ ${ }^{\mathrm{C}} \mathrm{CEPR}$, London, UK
}

Accepted 21 March 2003

\begin{abstract}
Assessing ten years of unique personnel data from a large firm, this paper investigates how determinants of worker turnover differ between periods of corporate expansion and decline. Performance and career progress considerably reduce the hazard of job separation during downsizing for blue-collar workers, but are less important for white-collar workers. Effects of firm-tenure, occupation, education, training, part-time status, and gender are largely in accordance with the implications from existing models. But no model generates all patterns observed in the data. Age effects are sensitive to retirement options and discontinuous, dropping in response to the anticipation of becoming eligible for early retirement during downsizing and jumping at the actual retirement age.

(C) 2003 Elsevier B.V. All rights reserved.
\end{abstract}

JEL classification: J63; J26; M12

Keywords: Worker turnover; Personnel economics

\section{Introduction}

This paper asks how determinants of worker turnover differ between times of corporate expansion and corporate decline. We exploit a unique personnel data set from a very large firm to analyze the determinants of job separations. The data set has detailed information on the internal labor market careers of 17,610 workers employed during a

\footnotetext{
* Corresponding author. Tel.: +49-228-3894-531; fax: +49-228-3894-510.

E-mail address: dohmen@iza.org (T.J. Dohmen).
} 
ten year period which is marked by an episode of corporate expansion and an episode of severe downsizing leading to bankruptcy in the end, so that we can assess how the determinants of separation rates modify when economic conditions change. Since we have information on performance evaluations and promotions, we investigate in particular how career development affects job separation in a nonstationary corporate environment.

At least two important aspects differentiate our study from previous empirical work that investigated the relationship between separation rates of workers and their characteristics (e.g. Farber, 1994; Gautier et al., 1999). First, rather than using data sampled over different firms and/or over different industries, we have data on the entire population of workers from a single firm during a period of almost ten years. Heterogeneity emanating from firm-specific or industry-specific effects is less of a concern since all workers face the same set of personnel policies. In addition, the personnel data are less prone to measurement error and recall problems than survey data. The second new characteristic of our analysis is that our data cover a period of corporate growth and an episode of corporate decline. The analysis of such data not only adds an additional dimension to the evaluation of theories of worker turnover, but is also relevant for labor market flow theories in general. ${ }^{1}$

We estimate hazard rates for the event of a job separation. In order to allow for a flexible baseline hazard, we choose a Cox proportional hazard model and reverse the role of calendar time and tenure duration to control for the nonstationary environment. We prefer a flexible parameterization of the duration dependence and the functional form of the dependence on other covariates. Although flexibility comes at the price of efficiency loss, the size and quality of our data set enables us to achieve a high degree of estimates' precision.

The results show that promotions lower turnover and that blue-collar workers with low performance evaluations, but not white-collar workers with low performance, are the first to leave in downturns. The effect of tenure, education, training, blue-collar vs. white-collar employment, and part-time work are in line with the predictions of turnover theories although no single theory can explain all facts. Consistent with theoretical predictions we find that young workers have higher separation rates, but we discover important discontinuities of separation hazards at older age resulting from early retirement options. Such institutional arrangements and the anticipation of them have important implications not only for the design of human resource policies, but also for empirical work because simple functional forms, such as a quadratic age effect, do not describe the data well and miss important features of reality.

The paper is organized as follows. The next section describes the data. Section 3 discusses implications of different models that we assess with our data. Section 4 presents the econometric model, a Cox proportional hazard model with calendar time dependence, which the data lend themselves to. Section 5 discusses the estimation results and their implications for the theoretical models. Section 6 concludes.

\footnotetext{
${ }^{1}$ How the determinants of worker turnover vary with the level of economic activity is a relevant question for flow theories of unemployment (e.g. Mortensen and Pissarides, 1994).
} 
Table 1

Fokker subsidiaries and plant locations

\begin{tabular}{lll}
\hline Subsidiary & Location name & Plant locations \\
\hline Fokker Administration & FAC1 & Amsterdam \\
Fokker Aircraft & FAC1 & Schiphol \\
Fokker Aircraft & FAC2 & Papendrecht/Dordrecht \\
Fokker Aircraft & FAC3 & Ypenburg \\
Fokker Space and Systems & FSS & Leiden \\
Fokker ELMO & ELMO & Woensdrecht \\
Fokker Special Products & FSP & Hoogeveen \\
Fokker Aircraft Services & FAS & Woensdrecht
\end{tabular}

Note: Fokker Administration is located in the city of Amsterdam. In the data, it has the same location name (FAC1) as the main assembly plant at Schiphol, which is due to historical reasons.

\section{The data}

The data come from the personnel files of the Dutch national aircraft manufacturer N.V. Koninklijke Nederlandse Vliegtuigenfabriek Fokker (Fokker N.V.). These files contain detailed information on the work histories of all 17,610 workers who had a permanent work contract with the firm at some time in the period from January 1, 1987, until March 15, 1996. ${ }^{2}$ During this period, Fokker N.V. was structured in an administration unit (Fokker Administration B.V.), an aircraft production unit (Fokker Aircraft B.V.), as well as four other subsidiaries (Fokker Space and Systems, Fokker ELMO, Fokker Special Products, and Fokker Aircraft Services). The core business, aircraft manufacturing, was organized in three plants of Fokker Aircraft B.V. (Schiphol, Papendrecht/Dordrecht, and Ypenburg) with headquarters, Fokker Administration B.V., in Amsterdam. The other four subsidiaries are vested in different locations (see Table 1 for an overview).

Distressed by the adverse economic conditions that had affected the entire industry from the early 1990s on, Fokker N.V., its production unit, and its administration unit filed for bankruptcy on March 15, 1996. ${ }^{3}$ The other viable parts of the firm - Fokker ELMO, Fokker Special Products, and Fokker Aircraft Services - did not enter the bankruptcy procedure and were sold. ${ }^{4}$

\footnotetext{
${ }^{2}$ The data were made available to us for academic purposes by the company's bankruptcy trustees. The report of the bankruptcy trustees is publicly available (Deterink et al., 1997).

${ }^{3}$ This might prompt the criticism that the firm is not a representative example of a downsizing firm as it fails eventually. However, there is reason to believe that the collapse came suddenly and unexpectedly. Most analysts expected that Fokker would survive. A comment in the Wall Street Journal on September 4, 1995, describes the market sentiment: "Few, however, expect DASA, the aerospace arm of German industrial giant Daimler-Benz AG, will let Fokker go bust. The Dutch company [...] fills a key niche in a market segment expected to show strong growth in the next few years" (du Bois, 1995).

${ }^{4}$ Fokker Space and Systems (FSS) had already been spun off in December 1995. Workers employed at this division leave our data files on that date.
} 
Panel (a) of Fig. 1 illustrates that demand in the two market segments for 40-70 seater and 70-125 seater aircraft, for which the firm produced, collapsed in 1990. The global slump in aircraft demand was partly a consequence of deregulation of the aviation industry. But the severity of the crisis resulted largely from adverse effects of the Gulf War on the aviation industry, which hit the firm unexpectedly. Panel (b) of Fig. 1 shows how employment dynamics responded to changes in aircraft demand. Employment in the entire company grew steadily from 10,215 permanent workers to 12,813 permanent workers from 1987 until 1991. Forced by the sharp global drop in aircraft demand, the firm announced the first of a series of reorganizations with workforce reduction on March 1, 1991. The vast majority of workers was employed in the company's core business operation, Fokker Aircraft, which was also affected most by the severe downturn.

The data lend themselves for duration analysis as they record each worker's accession and job separation date, birth date, as well as the timing of other relevant events, including changes in individual characteristics (education, training courses, marital status, and performance), job characteristics (hours worked, location of work), and compensation (position in the salary system).

\section{Implications from turnover models}

The joint expected surplus $S_{i t}$ of the employment relation between the firm and worker $i$ at time $t$ is the central theme that connects alternative turnover theories. It can be expressed as

$$
S_{i t}=V_{i t}-A_{i t}+\int_{t}^{T} \mathrm{E}_{t}\left(V_{i s}-A_{i s} \mid \Omega_{s}\right) \mathrm{d} s,
$$

where $V_{i t}$ denotes the value of the worker $i$ to the firm in period $t$ and $A_{i t}$ the value of the outside option to the worker. ${ }^{5} \mathrm{E}_{t}\left(V_{i s}-A_{i s} \mid \Omega_{s}\right)$ denotes the expectation of $V_{i s}-A_{i s}$ conditional on the information available at $t, \Omega_{t}$. The expected surplus is stochastic as future realizations of $V$ and $A$ depend on random shocks to productivity, demand, and prices. An option value exists, $O_{i t}$, as firms and workers can decide to separate in the future, thereby limiting losses. The option value of a separation is higher, the larger the variance of future surpluses. ${ }^{6}$

An efficient separation takes place if the joint expected surplus falls below the costs of separation $C$ and the option value $O$ associated with a separation. Inefficient separations can result when there are informational asymmetries about outside options (Hall and Lazear, 1984) or when specific investments are not verifiable (see Teulings and Hartog, 1998).

The probability that worker $i$ separates at time $t$ given that he did not separate before, $P_{i t}$, i.e. the hazard of job separation of worker $i$ at time $t$, is a function of the expected surplus net of separation costs and the option value of the separation,

\footnotetext{
${ }^{5}$ Without loss of generality, we have normalized the alternative option of the firm to equal zero.

${ }^{6}$ Pfann (2001) shows how uncertainty about the future creates an option value of waiting when separations are irreversible.
} 

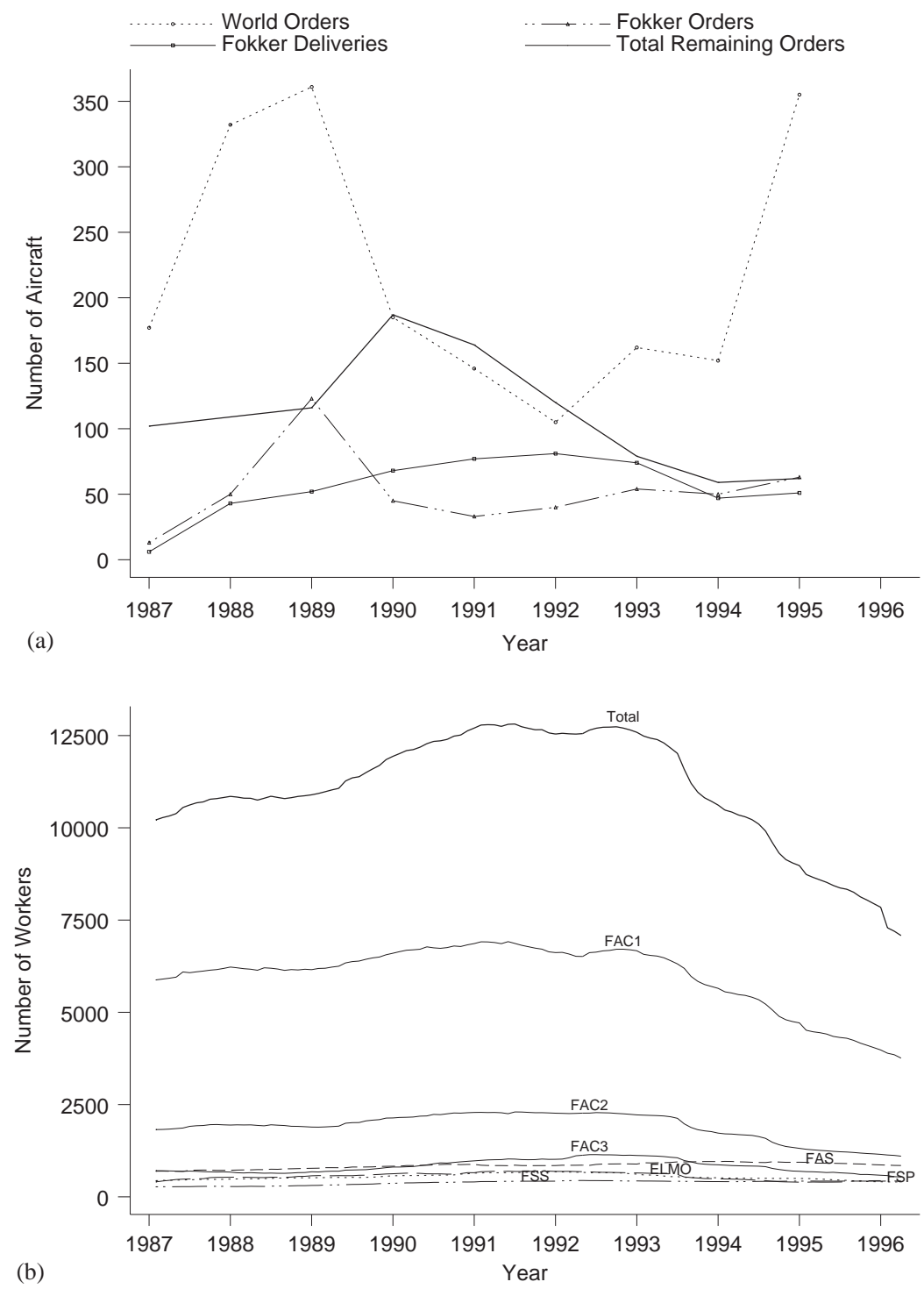

Fig. 1. Aircraft demand and employment dynamics. (a) Orders, deliveries, and remaining orders of aircraft and (b) workforce.

Notes: 1. Panel (a) shows the sum of total world orders, orders of Fokker aircraft, deliveries of Fokker aircraft, and total remaining orders for the two market segments of 40-70 seater and $70-125$ seater aircraft. Fokker orders shown in the figure are corrected for cancellations, and consequently do not include the option of 127 Fokker 100 aircraft, which were part of agreements with American Airlines and Guiness Peat Aviation that were placed in 1989 but that were never exercised. The numbers in the figure are based on information provided in Deterink et al. (1997). 2. Panel (b) plots the number of workers with a permanent contract employed in the entire firm (graph labelled "total") and its subsidiaries (FAC1, FAC2, FAC3, FAS, FSP, FSS, ELMO; see Table 1 for a definition) at the beginning of each month from January 1987 until March 1996. 
i.e. $P_{i t}=F\left(S_{i t}-C_{i t}-O_{i t}\right)$. Factors that augment the joint surplus are predicted to reduce the hazard of job separation. Match-specific capital (Jovanovic, 1979a) and relationship-specific investments (Oi, 1962), like firm-specific training are inversely related to turnover rates. Lower turnover rates, on the other hand, stimulate higher levels of specific investments. Firms could foster long-term employment relations by instituting a deferred compensation scheme (Lazear, 1979), which suggests that separation rates rise for older workers and workers with longer tenure when the firm is hit by a shock affecting the marginal value product. When firm-specific skills (Becker, 1962) or organization capital (Prescott and Visscher, 1980) is accumulated on-the-job, separations are negatively related to firm tenure (cf. Mortensen, 1978). The negative dependence of the separation hazard on job tenure is reinforced by decreasing search behavior in Jovanovic's (1979b) analysis which combines job-specific human capital accumulation and search behavior.

Since it is reasonable to assume that relation-specific capital is accumulated with job tenure at different rates (Dustmann and Meghir, 1998), we expect workers who have made careers within the firm (which we measure by upward mobility in the firm's salary scales) and workers with high performance evaluations to have lower separation rates, ceteris paribus.

\section{The econometric model}

The hazard of job separation is expected to change substantially with calendar time. Therefore, it is natural to estimate a mixed proportional hazard model in which we reverse the role of calendar time and duration as worked out by Imbens (1994). Since all workers in the data are employed at the same company, heterogeneity arising from firm-specific and industry-specific effects is ruled out in our application. By reversing the role of calendar time and duration, we control for unobserved heterogeneity that is independent of covariates, not individual-specific, and varying over time. Calendar time effects, i.e. the impact of nonstationary forces on the job separation hazard, enter the hazard rate through the baseline hazard and are not parameterized in the Cox proportional hazard model. A piece-wise constant step function

$$
\omega_{k}\left(t-t_{0}\right)=I\left[d_{k}<t-t_{0} \leqslant d_{k+1}\right]
$$

is specified to estimate the duration dependence of job tenure $\left(t-t_{0}\right)$ in a flexible way, where $I$ is the indicator function, $d_{k+1}-d_{k}$ a particular period length, and $t_{0}$ and $t$ are the entry date and the calendar date, respectively. The hazard rate $\lambda$ depends on calendar time $t$, on the accession date $t_{0}$, and on a set of time-invariant and time-varying characteristics in our design matrix $X$. The hazard rate is given by

$$
\lambda\left(t, t_{0}, X(t)\right)=\lambda_{0}(t) \exp X(t) \beta \exp \sum_{k=1}^{K} \alpha_{k} \omega_{k}\left(t-t_{0}\right) .
$$

Workers are in the risk pool from the starting date of analysis time, $t^{s}$ if they are employed at $t^{s}$ and their hiring date, $t_{0}$, is prior to the analysis time, i.e. $t_{0}<t^{s}$. Workers hired during the analysis time, i.e. for whom $t_{0} \geqslant t^{s}$, enter the risk pool at 
the day of accession to the firm. Workers leave the risk pool on the day of separation, or if their spell is censored. Such right-censoring occurs due to a worker's death or due to spin-offs in which workers do not lose their job but leave our data files as their employer changes. Since we know the beginning date of an employment spell, $t_{0}$, for all spells, we condition on elapsed tenure duration at the beginning of analysis time $t^{s}$ and, consequently, infer the duration dependence of employment spells.

In the estimation, we divide tenure duration into 27 intervals. In order to assess whether the separation hazard increases initially, we define intervals of one week for the first 12 weeks and of 3-months length for the remainder of the first year. Since the distribution of tenure at the firm is skewed, we enlarge the interval length at longer tenure choosing intervals of 1-year length for the second until the fifth year and of 5-years length thereafter. The covariance matrix $X$ includes controls for age, education, work-related training incidences, wage scales, performance evaluation scores, part-time work, gender, marital status, and having had a previous employment spell with the firm. ${ }^{7}$

In order to leave the functional form of the dependence on age flexible, we define a step function with yearly intervals. ${ }^{8}$ We include categorical dummy variables for the highest obtained schooling degree (see Table 2). ${ }^{9}$ We control for work-related training incidences by four variables, two of which are time-invariant and count, respectively, the number of external training courses completed before 1987 and the number of internal training courses completed before 1987, while the other two variables - the number of external and internal training courses completed during the observation period - vary over time. ${ }^{10}$

We account for the 18 different wage scales that exist at the firm. These wage scales also determine the split into white-collar and blue-collar employment. Workers in the 10 lower wage scales (scales 2-11), referred to as "blue-collar workers", are bound by collective wage bargaining agreements and are predominately employed in production. Workers in the higher scales (12-19) are referred to as "white-collar workers". Their wages are not bound by collective wage bargaining agreements. Most workers at the firm are blue-collar workers. We hold the first observed wage scale of a worker constant and include dummy variables that trace transitions in wage scales. By March 1991, only $0.4 \%$ of those who are still employed moved down the wage ladder. Upward moves are more common: $31.4 \%$ have moved up one scale, $17.7 \%$ two scales, and $7.9 \%$ three or more scales.

There are 6 performance evaluation scores for blue-collar workers and 5 for whitecollar workers, for each of which we define a dummy variable. Table 3 illustrates that the distribution of evaluation scores is left-skewed, but strongly concentrated around

\footnotetext{
${ }^{7}$ During the entire period, there are only 329 workers who are rehired.

${ }^{8}$ The age distribution among separating workers is not unimodal in the two periods. A first peak arises at the age of 25 years in both periods. The modal age at job separation is 60 years in the first period, but becomes 55 in the second period.

${ }^{9}$ We define the category "not reported" in order not to lose valuable information on those whose schooling degree is not reported in the data.

${ }^{10}$ Internal courses are training provided at the firm in the company's school, while external instructors are hired for external courses.
} 
Table 2

Schooling degrees

\begin{tabular}{ll}
\hline Education description & Type of education \\
\hline lo & Basic education \\
lbo & Lower vocational degree \\
mavo & Lower general schooling degree \\
llw & Apprenticeship \\
havo & Intermediate general schooling degree \\
mbo & Intermediate vocational degree \\
vwo & Higher general schooling degree \\
hbo & Higher vocational degree \\
uni & University/technical college \\
\hline
\end{tabular}

Note: The general schooling degrees, like basic education, lower, intermediate and higher general schooling degrees are prerequisites for pursuing a given vocational or general education in the Dutch educational system. Basic education is a prerequisite for any other degree. After having completed basic education, it is possible to either follow a lower vocational schooling course or to attend any of the school forms leading to a general schooling degree. Lower general education (mavo) makes one eligible to follow intermediate vocational training or complete an apprenticeship. An intermediate general schooling degree qualifies for higher vocational schooling, a higher general schooling degree (havo) qualifies for higher vocational schooling (hbo), while the highest level general schooling degree (vwo) is a prerequisite for pursuing a college or university degree. In addition, it is possible to pursue the next higher schooling level after having obtained a given schooling degree; similarly it is possible to enter the next higher level of vocational schooling after having completed vocational schooling at the level just below, e.g. after having completed intermediate vocational schooling one is eligible to enter higher vocational schooling.

Table 3

Definition and distribution of performance evaluation scores

\begin{tabular}{llclr}
\hline Score & \multicolumn{2}{l}{$\begin{array}{l}\text { Blue-collar workers } \\
\text { employed on March 1, 1991 }\end{array}$} & & \multicolumn{2}{l}{$\begin{array}{l}\text { White-collar workers } \\
\text { employed on March 1, 1991 }\end{array}$} \\
\cline { 2 - 5 } & Definition & Distribution & Definition & Distribution \\
\hline 1 & Falls behind & 0.13 & Unsatisfactory & 0.15 \\
2 & Unsatisfactory & 1.14 & Satisfactory & 2.89 \\
3 & Normal-good & 49.84 & Good & 84.65 \\
4 & Good-very good & 36.52 & Very good & 12.14 \\
5 & Very good-outstanding & 11.06 & Outstanding & 0.15 \\
6 & Excellent & 1.31 & & \\
Total & & 100.00 & & 100.00 \\
\hline
\end{tabular}

Performance evaluation scores are given by supervisors and must be approved of by the human resource department. Evaluation scores are typically given once a year after evaluation talks have taken place and refer to the performance in the past year.

the median: $86.4 \%$ of blue-workers employed on March 1, 1991, have scores in the categories "normal-good" or "good-very good" and $84.7 \%$ of the white-collar workforce were evaluated as "good". 
In order to account for the fact that the negative shock did not affect the different parts of the firm with the same intensity, we allow the baseline hazard to differ across plants. Moreover, we relax the assumption that nonstationary forces affect different groups of workers proportionally by stratifying the sample into white-collar and blue-collar workers. ${ }^{11}$

Since the determinants of relative separation rates might differ between times of expansion and downsizing, we estimate model (1) separately for the period of expansion and the period of downsizing, splitting the period on March 1, 1991, the day when the first downsizing operation was announced. Our analysis time of the second period ends on March 14, 1996, one day before the bankruptcy, when we censor observations of workers still employed on March 15, 1996.

We checked the robustness of our specification by restricting the parameter vector $\beta$ in different ways and by different forms of stratification. Coefficient estimates are generally robust in the sense that the exclusion of variables does not have a significant effect on other estimated coefficients. ${ }^{12}$ Coefficient estimates are also robust when the baseline hazard is allowed to differ across strata for gender or part-time workers.

\section{Estimation results}

\subsection{Baseline hazards}

An inspection of the baseline hazards, which are estimated separately for blue-collar and white-collar workers at the different plants, reveals large differences between the period of workforce expansion and the period of downsizing, thus highlighting the importance of controlling for nonstationarity. Fig. 2 plots the baseline hazards for blue-collar and white-collar workers at the largest subsidiary, FAC1. ${ }^{13}$ The hazard rate of a job separation is rather flat in the period of expansion until 1991, while it is much more erratic and considerably higher during downsizing, especially from 1993 onwards. The baseline hazard does not rise sharply between 1991 and 1993 when employment is contracting which suggests that workforce reductions prior to 1993 are mainly accomplished by reducing hiring and/or that job cuts are born largely by

\footnotetext{
${ }^{11} \mathrm{We}$ found important differences in baseline hazard rates for blue-collar and white-collar workers when we stratified the sample with respect to worker status. Since the fit of the model improves significantly when we stratify the sample, we estimate the parameter of model (1) separately for the sub-samples of blue-collar and white-collar workers.

${ }^{12}$ Leaving out dummies for wage scales affects estimated coefficients for education levels and measures of career attainment due to the high correlation between schooling credentials and wage scales. The impact of education on separation rates can, therefore, be decomposed into two effects: the effect of education given the job level and the effect of education on the probability of attaining a particular job level.

${ }^{13}$ The shape of the baseline hazard at other subsidiaries are similar, especially at the plants FAC2, and FAC3 which together with FAC1 constitute the core business aircraft manufacturing that accounts on average for $78 \%$ of employment.
} 


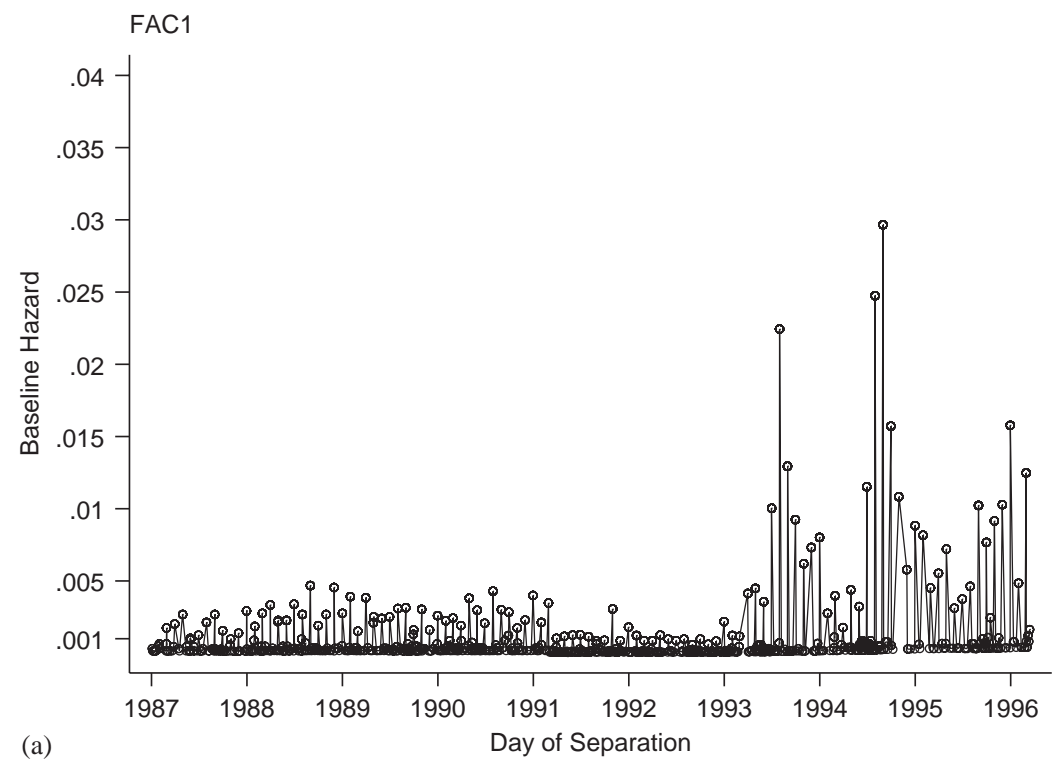

(a)

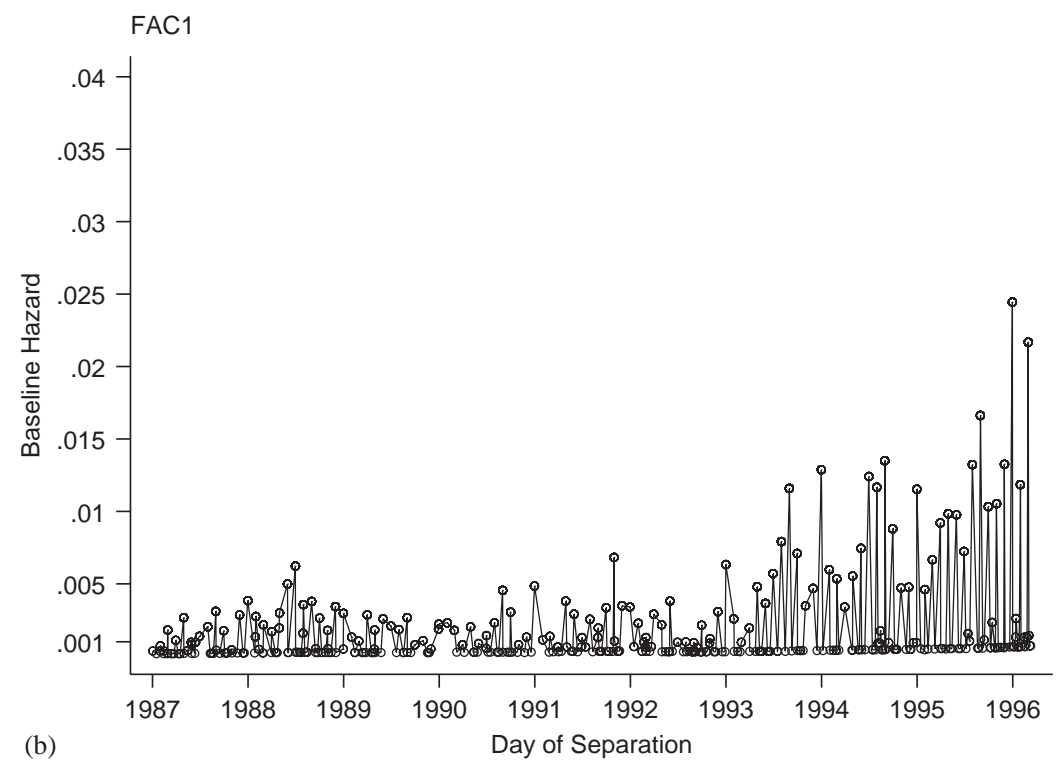

Fig. 2. Baseline hazards at FAC1. (a) Blue-collar workers and (b) white-collar workers. 
particular groups of the workforce. ${ }^{14}$ The baseline hazard rate peaks in 1993, 1994, and 1995 for both types of workers, but these peaks are more pronounced for blue-collar workers, especially in the earlier years 1993 and 1994. ${ }^{15}$ In fact, while white-collar workers are more likely to separate than blue-collar workers during expansion, the opposite is true during downsizing. ${ }^{16}$

\subsection{Promotions and performance}

Separation rates of workers in higher wage scales - and, therefore, workers in higher hierarchical positions ${ }^{17}$ - are less affected by downsizing. Relative separation rates of white-collar workers in the highest scales, scales 18 and 19, fall most, while blue-collar workers in the bottom scales (3-6) become more likely to separate. ${ }^{18}$

Promotions in wage scales have a strong and significant negative effect on separation rates for blue-collar workers in both periods. The more frequently a blue-collar worker is promoted, the less likely he becomes to separate. This effect becomes particularly strong during expansion. Having climbed up more than 1 scale does not affect the separation hazard of white-collar workers significantly in both periods, yet moving down in the salary system more than doubles the hazard of job separation (see Table 4) of white-collar workers during downsizing.

Performance evaluation scores have strong and significant effects throughout (Table 4). The better a worker's performance, the less likely he is to separate. This holds for both periods and both types of workers and is strong evidence for the general notion that low-surplus matches end early. Hazard rates of blue-collar workers with lowest scores are $78 \%$ higher than for those in the reference group during expansion and $458 \%$ during downsizing. Having an above median evaluation score becomes more important for job security of blue-collar workers in the period of downsizing as the $p$-values show. The effects of performance evaluations do not change for white-collar workers between the regime of workforce expansion and the episode of workforce contraction. This surprising difference in effects performance evaluations have on the turnover propensity of the two types of workers has not been found nor explained before.

\footnotetext{
14 This squares nicely with our prior knowledge that workforce reductions were mainly accomplished by usual attrition including retirement, but also early retirement prior to 1993 (Deterink et al., 1997) which shows up in an increase in the estimated age coefficient for workers at early retirement age.

${ }^{15}$ Hazard rates increase most markedly in 1993 at production sites of Fokker Aircraft (FAC1, FAC2, and FAC3). The hazard rate is highest at location FAC3 in 1995 when there were plans of closing that site. See Deterink et al. (1997) for more details on such plans.

${ }^{16}$ Such asymmetric downsizing may result from differences in adjustment costs and a perception that the crisis is temporary (cf. Hamermesh and Pfann, 1996).

${ }^{17}$ Hierarchical job levels and wage scales are strongly correlated.

${ }^{18}$ White-collar workers in the highest wage scale are typically assigned to the third highest hierarchical level. The 'Executive Board', which consisted of a group of three managers most of the time, and directors of subdivisions who compose the second highest hierarchy level are excluded from the study because information on their earnings history is not provided for confidentiality reasons.
} 
Table 4

Promotions and performance

\begin{tabular}{|c|c|c|c|c|c|c|c|}
\hline & & \multicolumn{3}{|c|}{ Blue-collar workers } & \multicolumn{3}{|c|}{ White-collar workers } \\
\hline & & 1987-1991 & 1991-1996 & $p$-values & 1987-1991 & 1991-1996 & $p$-values \\
\hline \multirow[t]{4}{*}{$\Delta$ Salary scale } & $<0$ & $\begin{array}{c}0.153 \\
(0.363)\end{array}$ & $\begin{array}{r}-0.205 \\
(0.178)\end{array}$ & 0.044 & $\begin{array}{c}-0.344 \\
(1.011)\end{array}$ & $\begin{array}{c}0.707 \\
(0.354)^{*}\end{array}$ & 0.003 \\
\hline & +1 & $\begin{array}{l}-0.424 \\
(0.064)^{* *}\end{array}$ & $\begin{array}{l}-0.148 \\
(0.041)^{* *}\end{array}$ & 0.000 & $\begin{array}{l}-0.449 \\
(0.154)^{* *}\end{array}$ & $\begin{array}{c}-0.089 \\
(0.086)\end{array}$ & 0.000 \\
\hline & +2 & $\begin{array}{l}-0.645 \\
(0.128)^{* *}\end{array}$ & $\begin{array}{l}-0.240 \\
(0.051)^{* *}\end{array}$ & 0.000 & $\begin{array}{c}0.194 \\
(0.203)\end{array}$ & $\begin{array}{c}-0.179 \\
(0.107)\end{array}$ & 0.000 \\
\hline & $\geqslant 3$ & $\begin{array}{l}-0.867 \\
(0.323)^{* *}\end{array}$ & $\begin{array}{l}-0.296 \\
(0.063)^{* *}\end{array}$ & 0.000 & $\begin{array}{c}0.012 \\
(0.249)\end{array}$ & $\begin{array}{c}-0.092 \\
(0.122)\end{array}$ & 0.395 \\
\hline \multicolumn{8}{|l|}{ Performance } \\
\hline \multirow[t]{6}{*}{ Score } & 1 & $\begin{array}{c}0.574 \\
(0.335)\end{array}$ & $\begin{array}{l}1.501 \\
(0.307)^{* *}\end{array}$ & 0.002 & $\begin{array}{l}3.011 \\
(0.284)^{* *}\end{array}$ & $\begin{array}{l}2.530 \\
(0.290)^{* *}\end{array}$ & 0.097 \\
\hline & 2 & $\begin{array}{l}0.832 \\
(0.113)^{* *}\end{array}$ & $\begin{array}{l}0.599 \\
(0.087)^{* *}\end{array}$ & 0.007 & $\begin{array}{c}0.643 \\
(0.140)^{* *}\end{array}$ & $\begin{array}{c}0.760 \\
(0.118)^{* *}\end{array}$ & 0.319 \\
\hline & 4 & $\begin{array}{l}-0.179 \\
(0.057)^{* *}\end{array}$ & $\begin{array}{c}-0.207 \\
(0.033)^{* *}\end{array}$ & 0.399 & $\begin{array}{c}-0.066 \\
(0.123)\end{array}$ & $\begin{array}{r}-0.086 \\
(0.087)\end{array}$ & 0.824 \\
\hline & 5 & $\begin{array}{c}-0.169 \\
(0.089)\end{array}$ & $\begin{array}{l}-0.426 \\
(0.062)^{* *}\end{array}$ & 0.000 & $\begin{array}{l}-1.345 \\
(0.540)^{*}\end{array}$ & $\begin{array}{l}-1.034 \\
(0.456)^{*}\end{array}$ & 0.495 \\
\hline & 6 & $\begin{array}{r}-0.153 \\
(0.150)\end{array}$ & $\begin{array}{l}-0.426 \\
(0.128)^{* *}\end{array}$ & 0.033 & & & \\
\hline & Missing & $\begin{array}{l}0.870 \\
(0.154)^{* *}\end{array}$ & & & $\begin{array}{c}-0.023 \\
(0.464)\end{array}$ & & \\
\hline Observations & & 189,988 & 135,195 & & 60,706 & 63,192 & \\
\hline
\end{tabular}

Notes: 1. The regression model includes regressors for tenure, age, education, training courses, wage scales, changes in wage scales, performance evaluation scores, marital status, gender, part-time work, an being rehired. 2. Reported coefficients measure the effect on the log hazard and ought to be interpreted as follows: A unit change in a covariate $x$ changes the log hazard by the amount of $\beta_{x}$, where $\beta_{x}$ is the estimated coefficient of covariate $x$. Since a unit change in $x$ changes the hazard by approximately $\beta * 100 \%$ for values of $\beta$ close to zero, we can interpret coefficients of categorical variables as semi-elasticities. 3 . The column labelled " $p$-value" reports the $p$-values for the test that the coefficient in the second period equals the point estimate of the coefficient in the first period, to give an indication whether coefficients differ in the two sub-periods. 4. Standard errors are in parentheses. An asterisk denotes that the coefficient is significant at the 5\% level, two asterisks denote significance at the $1 \%$ level. 5. Performance Evaluation Scores are defined in Table 3.

\subsection{Valuable specific skills}

Consistent with the predictions from turnover models, we find that workers with specific skills face lower separation rates. We also find that the separation rates of workers with more valuable firm-specific skills are affected less during downsizing.

First, the negative duration dependence after 1-2 years of tenure - see Fig. 3, which plots the elements of the estimated coefficient vector $\alpha$ from Eq. (1) for blue-collar and white-collar workers in the different period - is in agreement with the predictions of matching models (e.g. Jovanovic, 1979b) and models with specific capital 

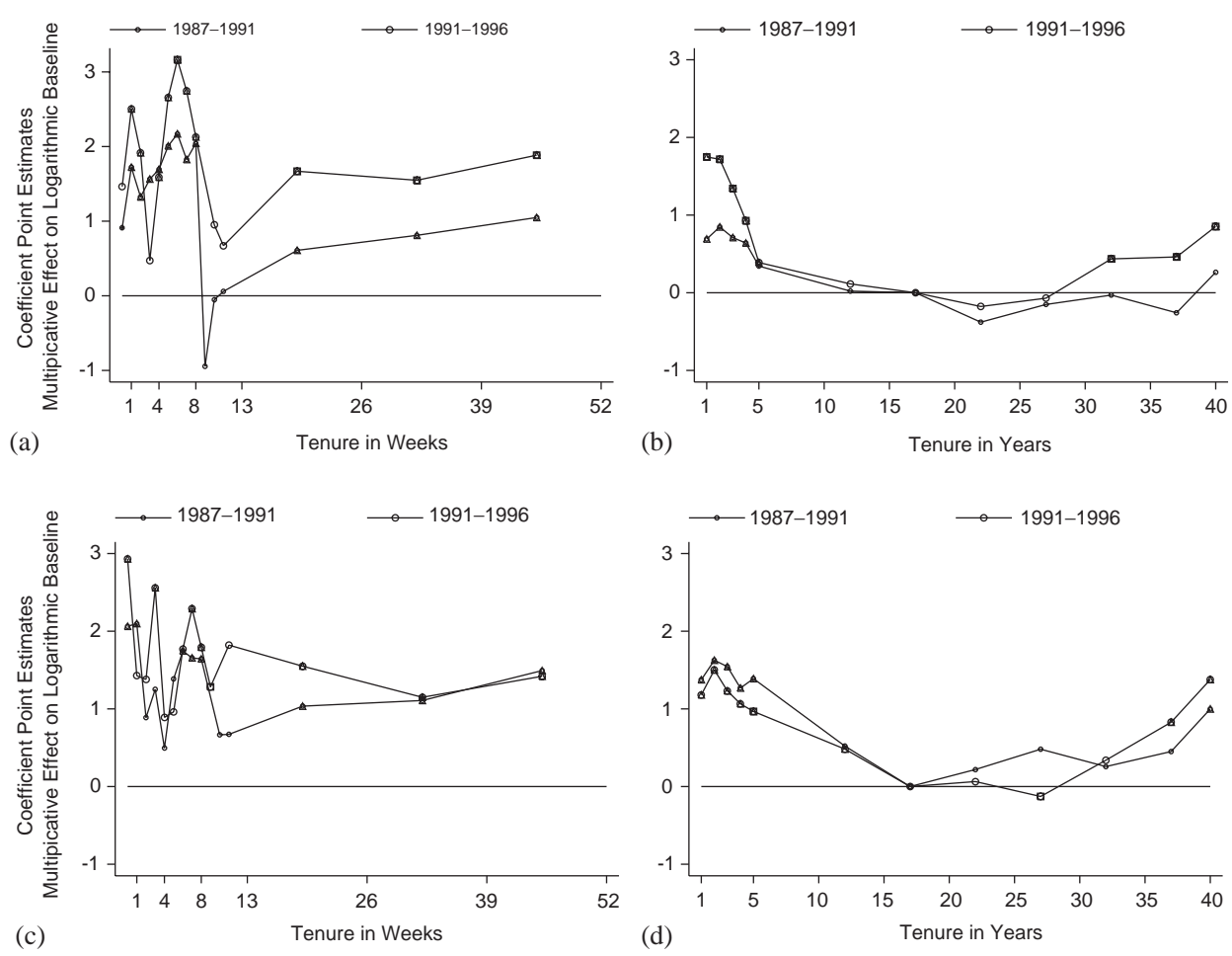

Fig. 3. Duration dependence of job tenure. (a) Blue-collar workers in first year, (b) blue-collar workers after first year, (c) white-collar workers in first year and (d) white-collar workers after first year.

Notes: Workers in the reference group are 35 years of age. Coefficient estimates that differ significantly at the $1 \%$-level are marked by triangles. A ' + ' denotes significance at the $5 \%$-level. A square indicates that the coefficient in the second period differs significantly $(1 \%$-level) from the coefficient point estimate in the first period.

accumulation on-the-job (e.g. Mortensen, 1978). The nonmonotonicity early during the employment relation is consistent with Jovanovic's (1979a) model that predicts rising separation rates in the first weeks of the employment relation, as it takes time for workers to accumulate sufficient "bad" information about their match that makes a separation optimal. ${ }^{19}$ The positive duration dependence at long job tenure can be ascribed to retirement.

Relative separation rates change during downsizing, when workers with 1-5 years of tenure and workers with more than 30 years of tenure become relatively more likely to separate. The higher hazard at short tenure, especially during the first 5 years, suggests that those who had least time to accumulate firm-specific skills, become more likely to

\footnotetext{
${ }^{19}$ Note that the models of Mortensen (1978) and of Jovanovic (1979b) do not generate the turnover pattern at the beginning of the match that Jovanovic (1979a) predicts and that we observe in our data. Jovanovic (1979a), on the other hand, neglects the effect of on-the-job human capital acquisition. Moreover, the model cannot explain a negative effect of experience on the separation hazard holding firm tenure constant.
} 
separate. ${ }^{20}$ The increase in the hazard rate at long tenure suggests that early retirement occurs more frequently in the period of downsizing.

Second, vocationally educated workers (lbo, llw, mbo, and hbo) have lower separation rates than those with a general education (lo, mavo, havo, or vwo). Blue-collar workers with an apprenticeship and white-collar workers with an intermediate vocational degree face the lowest separation rates. Since apprenticeships are commonly completed at Fokker and since such vocational schooling offered by the firm is likely to teach firm-specific skills and knowledge, our results (see Table 5) suggest that separation rates are lower the more firm-specific a worker's human capital is. ${ }^{21}$ In periods of turmoil, vocationally trained workers, especially blue-collar workers, and workers in more complex jobs, who commonly have attained higher educational credentials, face a lower increase in separation rates.

Third, a completed internal or external training course reduces the hazard rate of all workers significantly in the period of downsizing. Training courses completed prior to 1987 have a smaller effect on separation rates suggesting depreciation of skills acquired in these courses. ${ }^{22}$ Finally, workers who are rehired during the downsizing period face a lower risk of job separation, but the effect is not significant.

\subsection{Age}

Fig. 4, which plots the coefficient estimates for the different age categories for blue-collar (Panel (a)) and white-collar workers (Panel (b)), shows that the effects of age on separation rates are not smooth. The discontinuous drops and jumps around early retirement age are not captured adequately by common parametric specifications or lower order polynomials - even not by a seventh order polynomial. ${ }^{23}$

The hazard rate for blue-collar workers younger than 40 years of age is rather flat, while it decreases faster with age for white-collar workers. ${ }^{24}$ Different from the results

\footnotetext{
${ }^{20}$ A LIFO-layoff rule is also consistent with Kuhn and Robert's (1989) model of rent extraction. However, there is no evidence of an unconditional LIFO-layoff rule in our data, as workers with poor performance scores and workers with lower level educational degrees also become more likely to separate during downsizing.

${ }^{21}$ More than $57 \%$ of the workers who join the firm after 1987 and complete a higher degree during the employment spell complete an apprenticeship, $18 \%$ complete intermediate vocational schooling, $8 \%$ higher vocational schooling.

${ }^{22}$ It might seem puzzling that "external" courses which supposedly teach more general skills have a larger negative effect on the hazard than courses followed at the company. But since we only control for the number of courses, it is possible that courses provided by an external agency represent a larger investment in terms of hours and costs and their content might be partly firm-specific. A more puzzling result is that the effect of training courses is much lower and even insignificant for some types of courses in the second period.

${ }^{23}$ Existing studies often fit a quadratic age effect. Typically these studies estimate the minimum separation rates to occur at age 35-40. In fact, we have simulated this approach by also fitting a quadratic age effect in our data and found the minimum to be at age 36.8 for the pooled sample.

${ }^{24}$ General skills are typically more important for white-collar workers who are therefore more likely to engage in job-shopping.
} 
Table 5

Education and training

\begin{tabular}{|c|c|c|c|c|c|c|}
\hline \multirow[t]{2}{*}{ Highest degree } & \multicolumn{3}{|c|}{ Blue-collar workers } & \multicolumn{3}{|c|}{ White-collar workers } \\
\hline & 1987-1991 & 1991-1996 & $p$-values & 1987-1991 & 1991-1996 & $p$-values \\
\hline Not reported & $\begin{array}{c}0.559 \\
(0.075)^{* *}\end{array}$ & $\begin{array}{c}0.026 \\
(0.046)\end{array}$ & 0.000 & $\begin{array}{c}0.105 \\
(0.320)\end{array}$ & $\begin{array}{c}0.013 \\
(0.177)\end{array}$ & 0.606 \\
\hline lo & $\begin{array}{c}0.428 \\
(0.160)^{* *}\end{array}$ & $\begin{array}{r}-0.025 \\
(0.124)\end{array}$ & 0.000 & & & \\
\hline lbo & $\begin{array}{c}0.178 \\
(0.076)^{*}\end{array}$ & $\begin{array}{c}0.112 \\
(0.044)^{*}\end{array}$ & 0.134 & $\begin{array}{c}-0.531 \\
(0.374)\end{array}$ & $\begin{array}{c}0.021 \\
(0.237)\end{array}$ & 0.020 \\
\hline mavo & $\begin{array}{l}0.299 \\
(0.091)^{* *}\end{array}$ & $\begin{array}{c}0.032 \\
(0.060)\end{array}$ & 0.000 & $\begin{array}{r}-0.545 \\
(0.378)\end{array}$ & $\begin{array}{c}-0.043 \\
(0.246)\end{array}$ & 0.041 \\
\hline $11 \mathrm{w}$ & $\begin{array}{l}\text { Reference } \\
\text { group }\end{array}$ & $\begin{array}{l}\text { Reference } \\
\text { group }\end{array}$ & & $\begin{array}{l}\text { Reference } \\
\text { group }\end{array}$ & $\begin{array}{l}\text { Reference } \\
\text { group }\end{array}$ & \\
\hline havo & $\begin{array}{c}0.574 \\
(0.122)^{* *}\end{array}$ & $\begin{array}{c}0.077 \\
(0.097)\end{array}$ & 0.000 & $\begin{array}{c}-0.094 \\
(0.443)\end{array}$ & $\begin{array}{c}0.084 \\
(0.254)\end{array}$ & 0.485 \\
\hline mbo & $\begin{array}{l}0.292 \\
(0.082)^{* *}\end{array}$ & $\begin{array}{c}-0.007 \\
(0.051)\end{array}$ & 0.000 & $\begin{array}{l}-0.858 \\
(0.365)^{*}\end{array}$ & $\begin{array}{c}-0.271 \\
(0.188)\end{array}$ & 0.002 \\
\hline vwo & $\begin{array}{c}0.658 \\
(0.156)^{* *}\end{array}$ & $\begin{array}{r}-0.101 \\
(0.142)\end{array}$ & 0.000 & $\begin{array}{c}-0.218 \\
(0.351)\end{array}$ & $\begin{array}{c}-0.231 \\
(0.205)\end{array}$ & 0.950 \\
\hline hbo & $\begin{array}{c}0.349 \\
(0.168)^{*}\end{array}$ & $\begin{array}{c}0.153 \\
(0.134)\end{array}$ & 0.144 & $\begin{array}{c}-0.421 \\
(0.325)\end{array}$ & $\begin{array}{c}-0.260 \\
(0.180)\end{array}$ & 0.371 \\
\hline univ/th & $\begin{array}{c}-0.030 \\
(0.509)\end{array}$ & $\begin{array}{l}0.826 \\
(0.282)^{* *}\end{array}$ & 0.002 & $\begin{array}{c}-0.315 \\
(0.331)\end{array}$ & $\begin{array}{c}-0.164 \\
(0.187)\end{array}$ & 0.419 \\
\hline \multicolumn{7}{|l|}{ Training courses } \\
\hline Internal since 1987 & $\begin{array}{l}-0.067 \\
(0.009)^{* *}\end{array}$ & $\begin{array}{c}-0.005 \\
(0.003)\end{array}$ & 0.000 & $\begin{array}{l}-0.157 \\
(0.042)^{* *}\end{array}$ & $\begin{array}{l}-0.020 \\
(0.009)^{*}\end{array}$ & 0.000 \\
\hline External since 1987 & $\begin{array}{l}-0.183 \\
(0.064)^{* *}\end{array}$ & $\begin{array}{l}-0.055 \\
(0.018)^{* *}\end{array}$ & 0.000 & $\begin{array}{l}-0.197 \\
(0.063)^{* *}\end{array}$ & $\begin{array}{c}0.023 \\
(0.019)\end{array}$ & 0.000 \\
\hline Internal before 1987 & $\begin{array}{l}-0.017 \\
(0.005)^{* *}\end{array}$ & $\begin{array}{c}-0.009 \\
(0.004)^{*}\end{array}$ & 0.020 & $\begin{array}{c}0.006 \\
(0.013)\end{array}$ & $\begin{array}{c}0.007 \\
(0.008)\end{array}$ & 0.893 \\
\hline External before 1987 & $\begin{array}{c}-0.010 \\
(0.021)\end{array}$ & $\begin{array}{c}0.029 \\
(0.015)\end{array}$ & 0.011 & $\begin{array}{c}-0.012 \\
(0.029)\end{array}$ & $\begin{array}{c}-0.007 \\
(0.021)\end{array}$ & 0.814 \\
\hline Observations & 189,988 & 135,195 & & 60,706 & 63,192 & \\
\hline
\end{tabular}

Notes: 1. The regression model includes regressors for tenure, age, education, training courses, wage scales, changes in wage scales, performance evaluation scores, marital status, gender, part-time work, and being rehired. 2. Reported coefficients measure the effect on the log hazard and ought to be interpreted as follows: A unit change in a covariate $x$ changes the log hazard by the amount of $\beta_{x}$, where $\beta_{x}$ is the estimated coefficient of covariate $x$. Since a unit change in $x$ changes the hazard by approximately $\beta * 100 \%$ for values of $\beta$ close to zero, we can interpret coefficients of categorical variables as semi-elasticities. 3 . The column labelled " $p$-value" reports the $p$-values for the test that the coefficient in the second period equals the point estimate of the coefficient in the first period, to give an indication whether coefficients differ in the two sub-periods. 4. Standard errors are in parentheses. An asterisk denotes that the coefficient is significant at the $5 \%$ level, two asterisks denote significance at the $1 \%$ level. 5. Schooling variables are defined in Table 2 . The training course variables count the number of internal or external training courses that either have been successfully completed by a worker since January 1987 or that had been completed before January 1987. The latter set of variables is time invariant in the regression model. 

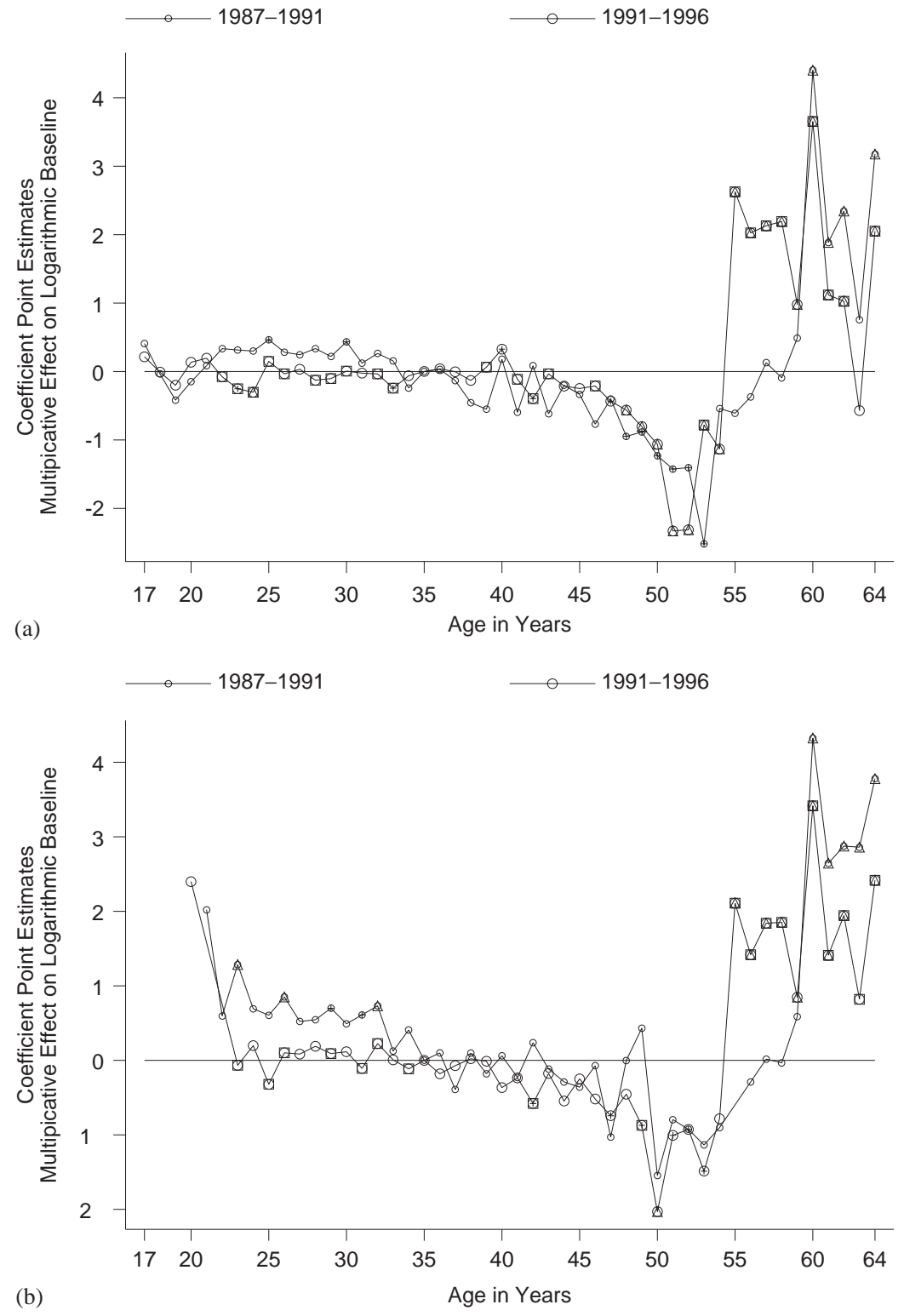

Fig. 4. Age effects. (a) Blue-collar workers and (b) white-collar workers.

Notes: Workers in the reference group are 35 years of age. Coefficient estimates that differ significantly at the $1 \%$-level are marked by triangles. A + denotes significance at the $5 \%$-level. A square indicates that the coefficient in the second period differs significantly (1\%-level) from the coefficient point estimate in the first period. 
in other studies, we find that hazard rates decline for workers in their forties and drop markedly at the age of 50. This drop is even more severe in the period of downsizing for blue-collar workers.

During the period of expansion, the hazard rate rises again for workers aged 54-59, and it jumps at the age of 60 when most workers retire to take advantage of an institutionalized early retirement scheme. During downsizing, when the firm offers early retirement plans or buyouts for workers aged 55 or older, the hazard jumps up for workers aged 55 and remains high thereafter. ${ }^{25}$ The value of the option to wait for becoming eligible for early retirement seems to be highest for workers aged 50-54 and their separation probabilities are, consequently, lowest. ${ }^{26}$ This result has important personnel policy implications for the design of early retirement plans. Early retirement schemes have strong spill-over effect on slightly younger workers that should be taken into account. Downsizing firms may want to offer less generous early retirement schemes to a broader group of workers in order to retain productive workers.

\section{Conclusion}

We have presented a case history analysis of worker mobility and compared the characteristics of turnover between prosperous and diminishing periods of a firm. We believe that many of the characteristics of turnover that we find are similar across firms so that we can learn something about other firms from our analysis. Our estimation results confirm many predictions of turnover models that relate inter alia to the effect of tenure, training, occupation, or part-time work. In addition, our results show that nonstationary forces cause relative separation rates to change.

Performance evaluation scores gain importance for blue-collar workers in periods of downsizing. In our data, this effect is not found for white-collar workers. Less than $2 \%$ of all workers get performance evaluation score in the lower third of the scale, but they face substantially higher job separation hazards. When turnover rates are high, as in periods of downsizing, individual separation hazards are much lower for those in the upper four deciles of the performance evaluation score distribution.

Career paths within the firm exhibit a dependence relation with a worker's turnover probability. The more frequently a blue-collar worker is promoted, the less likely he becomes to separate. This effect is stronger during expansion. The first promotion is important to lower a white-collar worker's turnover hazard during prosperous periods of the firm, but promotions do not matter in bad times. However, workers who experienced a demotion become much more likely to separate when the prospects of the firm worsen.

\footnotetext{
25 These early retirement plans guarantee workers an income stream of $85 \%$ of their last wage at Fokker as they receive a lump sum payment that is worth the capitalized value of $15 \%$ of their last wage for the time until they turn 60, when they become eligible for the "regular" early retirement scheme. In addition to this payment from the firm, social security provisions provides for an income stream of $70 \%$ of the last net wage until they enter into regular retirement.

${ }^{26}$ Stock and Wise (1990) also find sharp discontinuous jumps in retirement rates at specific ages.
} 
A final result of our study concerns the effect of age on separation rates, which is - driven by changes of the value of the retirement option - marked by important discontinuities, so that fitting a quadratic age effect may produce misleading results. As option values for retirement schemes change dramatically with the prospects of the firm, workers kill the option to retire early more frequently in periods of downsizing. However, if early retirement is offered only beyond a certain age, the option to retire early at a given age has important spill-over effects for slightly younger workers who, as a result, become less likely to separate. A downsizing firm should take this crowding out effect into account when designing early retirement plans. The role of retirement and its relation to worker turnover rates deserves a more careful treatment in future work on corporate downsizing and worker mobility.

\section{Acknowledgements}

This work has benefited from comments and suggestions on earlier drafts by James Brown, Joop Hartog, Guido Imbens, Boyan Jovanovic, Steve Pischke, Kathryn Shaw, Gerard van den Berg, Jan van Ours, and an anonymous referee. We would also like to thank seminar participants at Maastricht University, St. Gerlach, the IZA Summer School in Buch, the NAKE day in Amsterdam, the University of Aarhus, the annual meetings of the Society of Labor Economists in Austin, and the annual meetings of the European Economic Society in Lausanne. The authors like to thank Fokker's bankruptcy trustees, especially Mr. Ben Knüppe, for making the personnel data available, and Mr. Louis Deterink for sharing with us his profound knowledge and insights on corporate through-starts. Gerard Pfann thanks the N.W.O. PIONIER program for financial support. Thomas Dohmen acknowledges financial support from N.W.O. and SWOL. All errors are our own.

\section{References}

Becker, G.S., 1962. Investment in human capital: A theoretical analysis. Journal of Political Economy $70(5), 9-49$.

Deterink, A., Knüppe, B., Leuftink, A., Schimmelpenninck, R., 1997. Bankruptcy trustees' investigation of the causes of the bankruptcy of N.V. Koninklijke Nederlandse Vliegtuigfabriek Fokker. Fokker Aircraft B.V. and Fokker Administration B.V. Kluwer, Deventer.

du Bois, M., 1995. Aircraft maker Fokker faces a bumpy ride as Netherlands, DASA begin bailout talks. Wall Street Journal Europe, September 4.

Dustmann, C., Meghir, C., 1998. Wages, experience and seniority. IFS Working Paper W99/1.

Farber, H.S., 1994. The analysis of interfirm worker mobility. Journal of Labor Economics 12 (4), 554-593.

Gautier, P.A., van den Berg, G.J., van Ours, J.C., Ridder, G., 1999. Separations at the firm level. In: Haltiwanger, J.C., Lane, J.I., Spletzer, J.R., Theeuwes, J.J., Troske, K.R. (Eds.), Contributions to Economic Analysis: The Creation and Analysis of Employer-Employee Matched Data, Vol. 241. Elsevier Science, Amsterdam, The Netherlands.

Hall, R.E., Lazear, E.P., 1984. The excess sensitivity of layoffs and quits to demand. Journal of Labor Economics 2 (2), 223-257.

Hamermesh, D.S., Pfann, G.A., 1996. Adjustment costs in factor demand. Journal of Economic Literature 34 (3), 1264-1292. 
Imbens, G.W., 1994. Transition models in a non-stationary environment. Review of Economics and Statistics 76 (4), 703-720.

Jovanovic, B., 1979a. Job matching and the theory of turnover. Journal of Political Economy 87 (5), 972-990.

Jovanovic, B., 1979b. Firm-specific capital and turnover. Journal of Political Economy 87 (6), 1246-1260.

Kuhn, P.J., Robert, J., 1989. Seniority and distribution in a two-worker trade union. Quarterly Journal of Economics 104 (3), 485-508.

Lazear, E.P., 1979. Why is there mandatory retirement? Journal of Political Economy 87 (6), 1261-1284.

Mortensen, D.T., 1978. Specific capital and labor turnover. Bell Journal of Economics 9 (2), 572-586.

Mortensen, D.T., Pissarides, C.A., 1994. Job creation and job destruction in the theory of unemployment. Review of Economic Studies 61 (3), 397-415.

Oi, W.Y., 1962. Labor as a quasi-fixed factor. Journal of Political Economy 70 (6), 538-555.

Pfann, G.A., 2001. Options to quit. Economics Letters 70 (2), 259-265.

Prescott, E.C., Visscher, M., 1980. Organization capital. Journal of Political Economy 88 (3), 446-461.

Stock, J.H., Wise, D.A., 1990. Pensions, the option value of work, and retirement. Econometrica 58 (5), 131-159.

Teulings, C., Hartog, J., 1998. Corporatism or Competition? Cambridge University Press, Cambridge. 